\title{
Maternal outcome in cases of severe anaemia in labour
}

\author{
Shalini Singh*, Khushpreet Kaur \\ Department of Obstetrics and Gynecology, Government Medical College Patiala, Punjab, India
}

Received: 07 January 2018

Accepted: 03 February 2018

\section{*Correspondence:}

Dr. Shalini Singh,

E-mail: shalini4rocks@gmail.com

Copyright: $\odot$ the author(s), publisher and licensee Medip Academy. This is an open-access article distributed under the terms of the Creative Commons Attribution Non-Commercial License, which permits unrestricted non-commercial use, distribution, and reproduction in any medium, provided the original work is properly cited.

\section{ABSTRACT}

Background: Anaemia is the commonest medical disorder in pregnancy and severe anaemia is associated with poor maternal and perinatal outcome.

Methods: The study was done to analyse the characteristics of hospitalized pregnant women with severe anaemia (Haemoglobin $<7 \mathrm{gms} \%$ ) at the time of delivery and to find out maternal outcome. It was a prospective study done at Rajindra hospital, Patiala, Punjab, India over a period of one year from February 2016 to January 2017.

Results: Results were analysed; out of 3784 deliveries $210(5.54 \%)$ cases were severely anaemic at the time of delivery. Out of 210 women with severe anaemia $184(87.6 \%)$ patients belonged to low socioeconomic category, 177 $(84.2 \%)$ were unbooked cases, $152(72.4 \%)$ cases from rural area and $119(57.6 \%)$ cases were multi gravidas. The maternal complications were Pre-eclampsia and eclampsia (16.1\%), intercurrent infections (3\%), abruptio placentae (3.3\%), heart failure $(1.4 \%)$, preterm labours $(42.8 \%)$, intrauterine deaths $(10.9 \%)$ and postpartum haemorrhage $(10.4 \%)$.

Conclusions: Severe anaemia during pregnancy is associated with maternal and perinatal morbidity and mortality so effective preventive measures in the form of regular antenatal check-ups and iron supplementation will prevent complications of anaemia in pregnant women.

Keywords: Anaemia, Haemoglobin

\section{INTRODUCTION}

Anaemia is the commonest medical disorder in pregnancy and has a varied prevalence, etiology and degree of severity in different populations being more common in non-industrial countries. ${ }^{1}$

WHO defines anaemia in pregnancy as a haemoglobin concentration of less than $11 \mathrm{~g} / \mathrm{dl}$ and a haematocrit of less than $0.33 .^{2}$

It uses the following haemoglobin cut offs - 10.0 to10.9 $\mathrm{g} / \mathrm{dl}$ for mild anaemia, 7.0 to $9.9 \mathrm{~g} / \mathrm{dl}$ for moderate anaemia and lower than $7.0 \mathrm{~g} / \mathrm{l}$ for severe anaemia.

In India, more than $90 \%$ of anaemia cases are estimated to be due to iron deficiency because high iron requirement during pregnancy are not easily fulfilled by dietary intake especially when iron bio-availability is poor. ${ }^{3}$

Estimates of the WHO report that from 35\% to $75 \%$ (56\% on average) of pregnant women in developing countries and $18 \%$ of women from industrialized countries are anaemic. ${ }^{4}$ Principal blood changes during pregnancy.

This disproportionate increase in plasma and RBC volumes produces a state of haemodilution (fall in haematocrit) during pregnancy, which is more during second trimester leading to physiological anaemia. Anaemia is not only responsible for increase in maternal and perinatal morbidity and mortality but also severely affects economic and social status of the country. 
Table 1: Characteristics of blood during pregnancy.

\begin{tabular}{|lllll|}
\hline Characteristics & Non-pregnant & Pregnancy near term & Total increment & Change \\
\hline Blood volume $(\mathrm{ml})$ & 4000 & 5500 & 1500 & $+30-40 \%$ \\
\hline Plasma volume $(\mathrm{ml})$ & 2500 & 3750 & 1250 & $+40-50 \%$ \\
\hline Red cell volume $(\mathrm{ml})$ & 1400 & 1750 & 350 & $+20-30 \%$ \\
\hline Total Hb (gm) & 475 & 560 & 85 & $+18-20 \%$ \\
\hline Haematocrit (whole body) & $38 \%$ & $32 \%$ & & $-6 \%$ \\
\hline
\end{tabular}

\section{METHODS}

The present was a prospective observational and clinical study, conducted at Government Medical College and Rajindra Hospital, Patiala in Obstetrics and gynaecology department over a period of one year from February 2016 to January 2017. The pregnant women with severe anaemia in labour were included in the study, after fulfilling the inclusion criteria. A detail history and clinical examination was done as per proforma and required investigation were done. The maternal and perinatal outcome were noted. Inclusion criterias were $\mathrm{Hb}$ $\leq 7 \mathrm{gm} / \mathrm{dl}$, Singleton pregnancy, At the time of delivery. Exclusion criteria: pregnant women with hemoglobin $>7$ $\mathrm{gm} / \mathrm{dl}$, pregnancy with severe anemia due to acute hemorrhage multiple pregnancy, Women with chronic medical illness, women with blood dyscrasias and hemoglobinopathies. Frequencies and percentages were calculated to assess the distribution of the patient on the socio demographic variables such as age, living setting, religion, dietary habits, booked and unbooked status, parity and living children, degree of anaemia, number of blood transfusions given and mode of the delivery. The outcome of severe anaemia was seen in mother in form of preterm labour, preeclampsia, abruptio placentae, CHF, intercurrent infections and maternal mortality.

\section{RESULTS}

Number of deliveries during the study period was 3784 . Out of 3784 deliveries $210(5.54 \%)$ were severely anaemic.

Maximum women belonged to low socioeconomic status $(87.14 \%)$, living in rural area $(72.8 \%)$. Anaemia in pregnancy is more common in women of higher parity due to poor iron reserves.

Women with low socioeconomic status may not afford or have access to good maternal health care services because of lack of education or financial constraints. They are therefore more prone to the deleterious effects of poor nutrition, malaria, diarrhoeal diseases and chronic infections. Diminished intake and increased demands of iron, disturbed metabolism, pre-pregnant health status and excess iron demands as in multiple pregnancies, women with rapidly recurring pregnancies, blood loss during labour, heavy menstrual blood flow, inflammation and infectious diseases are important factors which lead to development of anaemia during pregnancy. There has been increased risk of anaemia among pregnant adolescents (teenage pregnancy) due to depleted iron stores that occurred during the adolescent growth spurt.

Table 2: Different factors of severely anaemic wom.

\begin{tabular}{|l|l|}
\hline Characteristics & No. of women $(\%)$ \\
\hline Age group & $19(9.0)$ \\
\hline$<20$ years & $90(42.8)$ \\
\hline 20-24 years & $68(32.3)$ \\
\hline $25-29$ years & $33(15.7)$ \\
\hline 30 and above & \\
\hline Socioeconomic status & $183(87.14)$ \\
\hline Lower & $27(12.8)$ \\
\hline Middle & \\
\hline Booked status & $32(15.2)$ \\
\hline Booked cases & $178(84.7)$ \\
\hline Unbooked cases & \\
\hline Residence & $153(72.8)$ \\
\hline Rural & $57(27.1)$ \\
\hline Urban & \\
\hline Parity & $83(39.5)$ \\
\hline Primigravida & $127(60.4)$ \\
\hline Multigravida & \\
\hline Gestational age & $121(57.6)$ \\
\hline$>37$ weeks & $56(26.6)$ \\
\hline $34-37$ weeks & $33(15.7)$ \\
\hline$<34$ weeks & \\
\hline
\end{tabular}

Table 3: Severe anaemia-associated maternal complications.

\begin{tabular}{|ll|}
\hline Complications & No. of women $(\%)$ \\
\hline Preterm labour & $89(42.8)$ \\
\hline Preeclampsia & $34(16.1)$ \\
\hline Post partum haemorrhage & $22(10.4)$ \\
\hline IUGR & $19(9.0)$ \\
\hline IUFD & $18(8.5)$ \\
\hline Sepsis & $8(3.8)$ \\
\hline Abruptio placentae & $7(3.3)$ \\
\hline Placenta previa & $5(2.3)$ \\
\hline Cardiac failure & $3(1.4)$ \\
\hline Mortality & $1(.47)$ \\
\hline
\end{tabular}

The commonest complication of severe anaemia observed in the present study was preterm labour showing highest incidence of 89 cases $(42.8 \%)$ followed by preeclampsia 
$(16.1 \%)$, intrauterine growth restriction $(9.0 \%)$, intrauterine death (8.5\%), sepsis (3.8\%), abruptio placentae in $3.3 \%$, placenta previa $(2.3 \%)$, cardiac failure in $1.4 \%$. Maternal mortality was seen only in one case $(0.47 \%)$. Cause of maternal mortality was decompensated cardiac failure due to severe anaemia superimposed with severe preeclampsia.

Anemia results in impaired transport of hemoglobin and thus oxygen to uterus, placenta and foetus. It also causes tissue enzyme and cellular dysfunction. This mechanism explains impaired myometrial contractility resulting in atonic uterus, as well as placental dysfunction leading to preterm birth, low birth weight and growth restricted babies and perinatal deaths. The susceptibility of women with severe anaemia to preeclampsia has been linked to deficiency of micronutrients and antioxidants. The reduction in serum levels of calcium, magnesium and zinc during pregnancy has been linked to the development of preeclampsia. Severe anaemia predisposes congestive heart failure as it causes circulatory overload due to increased stroke volume and tachycardia.

\section{DISCUSSION}

In India it is not uncommon to see patients with severe anaemia late in pregnancy with no prior antenatal visits especially in low socioeconomic settings and the same is evident from our study. Worldwide, it is estimated that 58.27 million women are anaemic during pregnancy, of whom 55.75 million $(95.7 \%)$ live in developing countries. In present study the prevalence of severe anaemia (Haemoglobin $<7$ gms\%) was $5.54 \%$ whereas study by Singhal et al observed the prevalence of $5.7 \%$ and Riffat jaleel reported $4.8 \%$ of severe anaemia in pregnant women. ${ }^{5,6}$ The age group 20-24 years had the highest prevalence of anaemia (68.4\%) which agrees with the findings of Rajeshwari and Ashok Kumar, and Rajaratnam et al. ${ }^{7,8}$

Anaemia prevalence was also significantly high in pregnant women from low socioeconomic status $(87.6 \%)$ compared to those from middle socioeconomic status (12.4\%). Studies from Allen et al, Rajaratnam et al and Bentley ME also reported the same observations. ${ }^{9,10}$

Table 4: Severe anaemia-maternal complication in different study group.

\begin{tabular}{|c|c|c|c|c|c|c|c|}
\hline Parameter & $\begin{array}{l}\text { A wasthi et } \\
\text { al }\end{array}$ & $\begin{array}{l}\text { Agarwal } \\
\text { R et al }\end{array}$ & Singhal et al & $\begin{array}{l}\text { Devi NB } \\
\text { et al }\end{array}$ & $\begin{array}{l}\text { Jaleel R } \\
\text { study }\end{array}$ & $\begin{array}{l}\text { Rohilla } \\
\text { M et al }\end{array}$ & $\begin{array}{l}\text { Present } \\
\text { study }\end{array}$ \\
\hline Preterm labour & $9.5 \%$ & $22 \%$ & $32 \%$ & $44.68 \%$ & $23.5 \%$ & $18.75 \%$ & $42.8 \%$ \\
\hline Preeclampsia & $28 \%$ & $7.1 \%$ & $19.33 \%$ & $25.33 \%$ & - & $17.7 \%$ & $16.1 \%$ \\
\hline Abruptio & - & - & $10.8 \%$ & $8.5 \%$ & $5.9 \%$ & $3.12 \%$ & $3.3 \%$ \\
\hline Placenta previa & - & - & $10.8 \%$ & $2 \%$ & - & - & $2.3 \%$ \\
\hline $\begin{array}{l}\text { Abruptio with placenta } \\
\text { previa }\end{array}$ & $10.5 \%$ & $0.68 \%$ & - & - & - & - & - \\
\hline $\mathrm{PPH}$ & $7.5 \%$ & $0.4 \%$ & $7.6 \%$ & $6.4 \%$ & $9.8 \%$ & $25.5 \%$ & $10.4 \%$ \\
\hline IUGR & $37.5 \%$ & - & $6.62 \%$ & $12.77 \%$ & $27.8 \%$ & $33.33 \%$ & $9.0 \%$ \\
\hline $\mathrm{CHF}$ & - & - & $4.97 \%$ & $1.06 \%$ & $1.9 \%$ & $9.37 \%$ & $1.4 \%$ \\
\hline Mortality & - & - & - & $1.06 \%$ & $1.9 \%$ & $6.25 \%$ & $0.47 \%$ \\
\hline
\end{tabular}

Boniface et al also reported that obstetric risks were more in unbooked pregnant women compared to booked ones. ${ }^{11}$ There may be expected decline in haemoglobin level due to haemodilution, increasing fetal demand, underlying maternal infection and untreated anaemia in early pregnancy may also get worse with advancing pregnancy.

The booked patient benefits from focused antenatal care objectives, which is proven to reduce maternal and fetal morbidity/mortality, have obvious benefits in terms of risk assessment, active management, correction of modifiable conditions, and boosting the psychological support and family preparedness for a new child.

Preterm labour was more common in present study with $42.8 \%$. Incidence in Singhal et al study it was $32.59 \%$,
22\% in Agarwal R study, 9.5\% in Awasthi et al study $23.5 \%$ in Jaleel $\mathrm{R}$ study and $18.75 \%$ in Rohilla $\mathrm{M}$ et al. ${ }^{5,12-14}$ Pregnancy induced hypertension in present study was $16.1 \%$, In Singhal et al study it was $19.33 \%$, Awasthi et al study it was $25.33 \%$ and Rohilla $\mathrm{M}$ et al study it was $17.7 \%$. The results of present study correlate well with Singhal et al study and Devi NB et al study. ${ }^{15}$

Women with low socioeconomic status may not afford or have access to good maternal health care services because of lack of education or financial constraints. They are therefore more prone to the deleterious effects of poor nutrition, malaria, diarrhoeal diseases and chronic infections. Increased risk of anaemia was observed in the pregnant women who were unbooked at the time of the delivery as compared to the booked pregnant women. 


\section{CONCLUSION}

Anaemia in pregnancy is a major health problem in developing countries. Anaemia contributes significantly to maternal and perinatal morbidity and mortality. By keeping this in view, it is recommended that good antenatal care should be made available, accessible and affordable to all pregnant women through partnership between all tiers of government and non-governmental organizations. New and innovative strategies are needed, particularly those that improve the overall health and nutrition status of adolescent girls before they enter their reproductive years.

Early marriages and teenage pregnancies are better avoided. Awareness created regarding dietary habits, small family norms, birth spacing, regular antenatal check-ups and regular intake of iron. Efforts therefore need to be directed not only to correct anaemia but to prevent anaemia, so that we can achieve the millennium development goal of reducing the maternal mortality rate by three quarters.

Funding: No funding sources

Conflict of interest: None declared

Ethical approval: The study was approved by the Institutional Ethics Committee

\section{REFERENCES}

1. Benoist B, Mclean E, Egli I, Cogswell M. Worldwide prevalence of anaemia 1993-2005. WHO Global Database on Anaemia. Worldh Health Organization; 2008.

2. Iron deficiency anaemia: assessment, prevention, and control. A guide for programme managers. Geneva, World Health Organization; 2001 (WHO/NHD/01.3).

3. CDC criteria for anaemia in children and childbearing-aged women. MMWR Morb Mortal Wkly Rep; 1989;38:400-4.

4. WHO. The global prevalence of anaemia in 2011. Geneva: World Health Organization; 2015.
5. Singhal SR, Nanda S, Sangwank M. Sharma D. Maternal and Perinatal outcome in severe Anaemia. Indian Practitioner. 2007;60(11):691-4.

6. Jaleel RI, Khan A. Severe anemia and adverse pregnancy outcome. J Surg Pak (International). 2008;13(4):147-50.

7. Rajeshwari K, Behera AK. The study of incidence of maternal anaemia in various age groups of women going to labour in Orissa. International Journal of Recent Trends in Sci Technol. 2014;12(2)250-2.

8. Rajaratanam JY, Rajaratanam A, Ganesan C. Jayaseelan SA. Maternal anaemia: persistent problem in rural Tamil Nadu. Natl Med J Ind. 2000:242-5.

9. Allen LH. Biological mechanisms that might underlie iron's effects on fetal growth and preterm birth. J Nutr. 2001;131(2S-2):S581-9.

10. Bentley ME and Griffiths PL. The burden of anaemia among women in India. Eur J Clin Nutr. 2003;57:5260.

11. Ago BU, Abeshi S, Njoku C, UdagborAgan $\mathrm{T}$ and Ekabua J. Obstetric outcomes of booked teenage pregnancies at University of Calabar Teaching Hospital, Nigeria. Adolescent Health Med Therapeutics. 2012;3:105-9.

12. Agarwal R. Medical officer, Medical Hospital, Agra; A Multi centric study of anaemia. A step in conquering anaemia. Obstet Gyecol. 2003;8(11):6203.

13. Awasthi A, Thakur R, Dave A, et al. Maternal and Perinatal outcome in case of Moderate and Severe Anaemia Complicating pregnancy J Obset Gynaecol India. 2001;5-51.

14. Rohilla M, Ravindra A, Dhaliwal LK, Chopra S. Severe anaemia in pregnancy: A territory hospital from Northen India. J Obset Gynaecol. 2010:30 (7):694-6.

15. Devi NB, Varalaxmi B, Jyothirmayi T, Lahari N. Maternal outcome in pregnancy with severe anaemia: Prospective study in a tertiary care hospital in Andhra Pradesh. IOSR-JDMS. 2015;14:6-10.

Cite this article as: Singh S, Kaur K. Maternal outcome in cases of severe anaemia in labour. Int $\mathbf{J}$ Reprod Contracept Obstet Gynecol 2018;7:1201-4. 